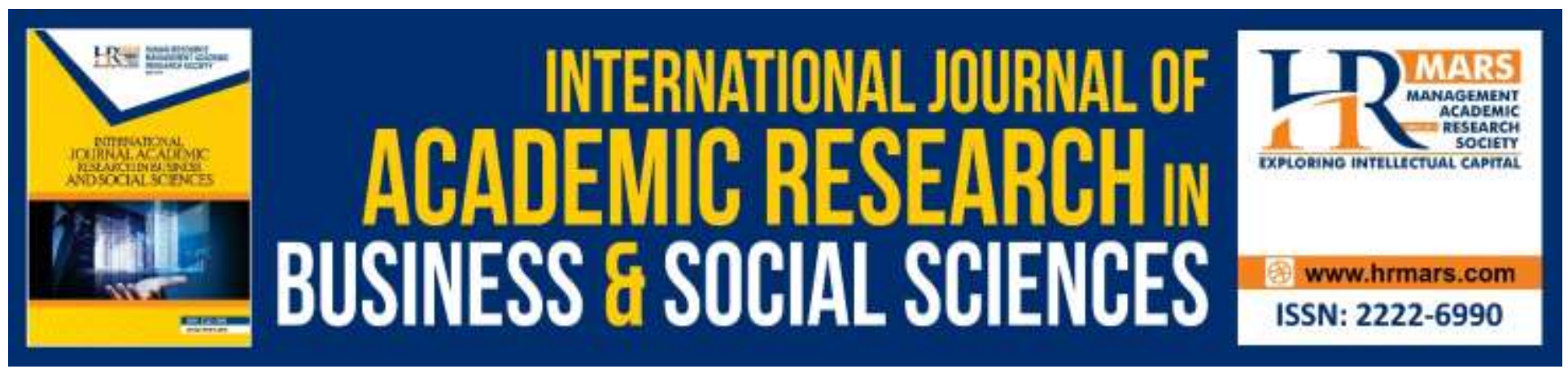

\title{
Mother-Child Relationship and Education on Sexuality
}

Noradila Mohamed Faudzi, Melati Sumari, Azmawaty Mohamad Nor

To Link this Article: http://dx.doi.org/10.6007/IJARBSS/v10-i3/7092

DOI:10.6007/IJARBSS/v10-i3/7092

Received: 01 February 2020, Revised: 23 February 2020, Accepted: 14 March 2020

Published Online: 27 March 2020

In-Text Citation: (Faudzi et al., 2020)

To Cite this Article: Faudzi, N. M., Sumari, M., \& Nor, A. M. (2020). Mother-Child Relationship and Education on Sexuality. International Journal of Academic Research in Business and Social Sciences, 10(3), 787-796.

Copyright: (C) 2020 The Author(s)

Published by Human Resource Management Academic Research Society (www.hrmars.com)

This article is published under the Creative Commons Attribution (CC BY 4.0) license. Anyone may reproduce, distribute, translate and create derivative works of this article (for both commercial and non-commercial purposes), subject to full attribution to the original publication and authors. The full terms of this license may be seen at: http://creativecommons.org/licences/by/4.0/legalcode

Vol. 10, No. 3, 2020, Pg. 787 - 796

http://hrmars.com/index.php/pages/detail/IJARBSS

JOURNAL HOMEPAGE

Full Terms \& Conditions of access and use can be found at http://hrmars.com/index.php/pages/detail/publication-ethics 


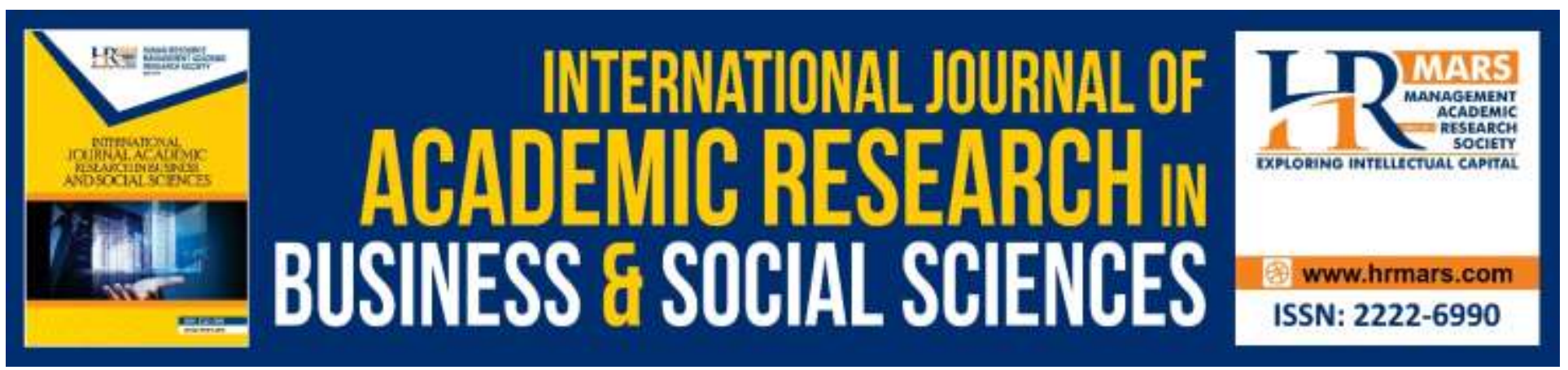

\title{
Mother-Child Relationship and Education on Sexuality
}

\author{
Noradila Mohamed Faudzi,Melati Sumari,Azmawaty Mohamad Nor \\ Department of Educational Psychology and Counseling, University of Malaya, Malaysia
}

\begin{abstract}
Mother-child relationship is an important relationship in family, and it is providing a base for children to expand the relationship with others. Through the development of child, adolescences period is a critical development which is regularly understood as the years between the beginning of puberty and the initiation of social independence. Adolescence is a time where by experiencing pubertal changes, brain structures and sexual interest and to understand on their changes, it will be help through education. Mother is one of the persons who are responsible in education of adolescents especially in sexuality. In Malaysia the pregnant adolescents are excluded from the mainstream school education system, so special attention on education of sexuality are needed in order to curb the social problem like unwanted pregnancy among adolescents. Sexuality education has been shown to help to prevent and reduce the risks of adolescent pregnancy, HIV, and sexually transmitted infections for children and adolescents. Therefore, mother's role is pertinent in educating their children on sexuality issues. This paper intends to provide an overview on education of sexuality in mother-child relationship and how the education of sexuality can be implemented at home. The importance of sexual education and the implication for practitioner are also discussed.
\end{abstract}

Keywords: Mother-Child Relationship, Sexuality Education, Adolescents

\section{Introduction}

\section{A Mother-Child Relationship}

Nowadays, life as adolescents is challenging as compared to the life of adolescents in the past and this might affect the parents as well. One of the important persons for child is a mother. How a good mother-child relationship will lead to better child behavior. There is a study indicated specificity in the associations between mother-child relations and child behavior negativity in mother-child relationships predicted behavioral problems, whereas positivity in mother-child relationships predicted prosocial behavior (Mark \& Pike, 2016). As the child grow up and become adolescents the needs of figure of mothers is bigger, where a study has found that positive changes in the perceived quality of the attachment with mothers were related to a positive change in the self-esteem of both sons and daughters (Keizer, 2019). Also, it can be seen in a research, adolescents' relationship with mother was found to be more dominant than their relationship with father (Walper, 2015). So, due to the challenging path that the adolescents need to face, the mother also needs to play continuing 
INTERNATIONAL JOURNAL OF ACADEMIC RESEARCH IN BUSINESS AND SOCIAL SCIENCES Vol. 10, No. 3, March, 2020, E-ISSN: 2222-6990 @ 2020 HRMARS

role to ensure the safety and well-being of adolescents. Apart from that, is pertinent to understand the development of adolescents, where mothers can understand the concept of adolescent's development including the sexuality development and it will be easier for mother to get close with their adolescents. The mothers can educate their child about sexuality because a study has demonstrated that most participants believe that sexual health education for adolescent girls must be initiated by mothers at home (Shams, Parhizkar, Mousavizadeh, \& Majdpour, 2017). Another study also showed, that adolescents tended to point more open and often to communicate with mothers rather than fathers, also the have warm relationships with mothers, so that the adolescents tended to generally discuss sexual issues with their mothers (Muhwezi et al., 2015).

\section{Adolescent Sexuality Development Stage of Development}

Adolescents stage is a crucial time for development. There are many changes and development that happens in adolescence period. During adolescence, the physical growth, psychological as well as cognitive get to the highest and the top of development. One of the developments that occurs is sexuality in adolescent. Adolescent sexuality development can be effectively described with the biopsycho-social model. In determining, the development of sexuality in adolescents it has consider looking at the biological psychological, also social factors which have the equal importance's in development (Kar, Choudhury \& Sigh, 2015). All the factors are contributed to the adolescent development but there is no fundamental difference between adolescents and adults regarding sexuality development. The development potentially continues long beyond adolescence and can be promoted through education regardless of age Basically, adolescence is a time for sexual exploration and expression. For many adolescents' sexual relations begin in adolescence, in or outside of marriage. At the early age of adolescent, they tend to explore and evaluate about their self, then in the middle of adolescent, they are testing ability to attract opposite sex and preoccupation with romantic fantasy (WHO, 2018).

Sexuality development lies on a persistence along which young people proceed in the context of relationships and is a healthy, natural part of life. Adolescents involved in relationships that may embrace a variety of sexual activities (Pfeffer \& Ellsworth, 2017). Understanding the physiological influences that drive adolescent sexual activity, such as hormonal, chemical and neurological reactions and changes, can help inform interventions to support adolescents in making appropriate choices regarding their sexual behavior (Pringle et al., 2017). If the parents especially the mother can understand the sexuality development of their adolescent it will easier to the mother in supervise and communicate with their adolescents. The communication between mother and child will help the adolescent to clear all the myths or misinformation that adolescence faced. Therefore, the roles of mother are pertinent in helping adolescent through their journey.

\section{Literature Review Roles of Mother}

Mostly parents and their children, avoided the discussion about topic related to sexuality because it creates the anxiety and apprehension. Parents may also refrain discussions about sexuality because they are afraid of putting ideas into their child's head before they are "ready" or because they liken to talking about sexuality with giving tacit permission to explore sexual behaviors. (Ashcraft \& 
INTERNATIONAL JOURNAL OF ACADEMIC RESEARCH IN BUSINESS AND SOCIAL SCIENCES Vol. 10, No. 3, March, 2020, E-ISSN: 2222-6990 @ 2020 HRMARS

Murray, 2017). This is the normal scenario happened in most family, but the parents or caregivers should know that their role in sexual education is crucial. Normally, the primary caregiver in this society also known as mother, so here the vital roles should be play by the mother in educating adolescents about sexuality.

A study on mother's perception about sexuality have shown that $80 \%$ agreed that children needed sexuality education but only $9.5 \%$ had a good knowledge on the concept of education sexuality (Opara, Eke \& Akani, 2010). A study in Namibia has mention most parents do not talk openly to their children about issues of sexuality. When the subject of sexuality comes up in these communities, most parents give unclear messages to their children(Lukolo \& Dyk, 2015) The major barriers identified by the mothers were their own insufficient knowledge about sexual issues, embarrassment surrounding discussions of this issue with their daughters, fear of the arrogance and curiosity of girls, and a lack of skills for effective communication(Shams et al., 2017). In this sense we can see that the mothers recognize the need for children to be informed but lack adequate knowledge to do this.

Besides that, the parenting style also influences understanding on sexuality education. In a research about communication between mother-daughter's communication on sexuality stated that authoritative parenting style was related to the number of topics communicated about and was a predictor of age of daughter at the time of communication about sexual intercourse, menstruation, dating/relationships, sexually transmitted diseases (STDs), HIV/AIDS, alcohol, contraceptives, and abstinence, while perceptions of risk were not significant influencers of age at the time of communication for any topics (Askelson, Campo \& Smith, 2012).

Other than that, there is a study about the sexual communication between mothers and daughter, and the results shows, overall, sexual communication is not challenging for these mothers and daughters, who are seemingly in very close relationships. Both, mother and daughter thinking that the perception of sex as a natural topic prompted these mothers and daughters to be open about sex during their relational discourse but when they started to talk openly about sex, the challenge was acknowledged. The mothers were challenged by the process of what sexual information to disclose and when is the right time to talk (Coffelt, 2010). So, here the mothers need to make sure what are the key points that they want to convey to their child and the right age before openly to talk about sex with them. Meanwhile, other study has stated differently, because the study found that Black mother-daughter communication about sexual relationships is typically externally prompted, characterized by negative messages, and often uncomfortable for both mothers and daughter (Dennis \& Wood, 2012). There need to be a proper way that a mother can talk about sexuality (Ashcraft \& Murray, 2017), so the conversation will not be awkward and too serious.

In some countries like in Kenya, the main barrier to meaningful sex education between mothers and their daughters was taboos that prevent parents from discussing sex with their children In Kenya, the study showed most mothers had no sex education either from their parents or other family members and hence could not talk about sex to their own daughters. Similarly, parents in three cities in different regions of the United States complained that their parents never talked to them about sex; therefore, it was difficult for them to know how to talk about sex to their own children (Baku, Agbemafle, Kotoh \& Adanu, 2018).

For Muslim mothers, they can use the religion as a guidance that might help in educating about sexual knowledge, a study has mention that having faith in religion and strong sexual desire were the main themes that explained participants' sexual behavior. In preventing female students from being 
INTERNATIONAL JOURNAL OF ACADEMIC RESEARCH IN BUSINESS AND SOCIAL SCIENCES Vol. 10, No. 3, March, 2020, E-ISSN: 2222-6990 @ 2020 HRMARS

sexually active, then engaging in religious activity will be effective to them. However, if sexual urges and desires are beyond control then religiosity might not be helpful at all (Muhammad, Shamsuddin, Sulaiman, Amin \& Omar, 2016). Another study has mention that the needs of religiosity in prevent the externalizing behavior among Muslim adolescents (Kadri, Zulkefly, \& Baharudin, 2019). A study has proved, the bivariate analysis indicated that religious belief is significantly related with sexual knowledge. Thus, religious leaders need to be tactful in communicating sex related issues to adolescents. Adolescents always question the social standard, yet they need moral guidance in shaping their values. Hence, religion may have a contingent effect in form attitude toward healthy sexual development among adolescents (Y, Fui-ping, Rozumah, Mariani \& Rumaya, 2010).

It is evident that, the roles of mothers in raising their adolescents are challenging. The mother needs to communicate well, applying the right parenting style, provided full of knowledge regarding sexuality and religiosity as a guidance. Other people also have responsibility to convey and spread the awareness on education of sexuality. With the full cooperation with communities and authorities it will be powerful in enhancing the understanding of sexuality education among adolescents.

\section{Educating Adolescent about Sexuality Talking to Parents}

Secondary education will be expected to be the obvious place for promoting adolescent sexuality development (Moshman, 2014) However, information about sexuality can be taught and shared not only in schools, but the communities, family at homes, and medical offices using evidence-based interventions also can educated the adolescents about sexuality (Breuner \& Mattson, 2016). Fortenberry (2013), also stated that family, peers, and partners are sources of knowledge and experience and provide reference points for interpretation and meaning. Schools and religious organizations channel cultural values and knowledge, as well as giving infrastructure for sexual learning and experiences. Parents should play vital role in conveying the knowledge content about sexuality. Besides that, parents should communicate comprehensive, medically accurate information about sexuality to their adolescents. (Ashcraft \& Murray, 2017). Most of the parent-adolescent sexual discussions were based on physical changes, personal hygiene, abstinence, abortion, and saying "no" to forced sex. Parents discussed sexuality issues with adolescents to prevent them from premarital sex, pregnancy, and sexually transmitted infections. Apart from that parents sourced their knowledge about sexuality from books, television, radio, and personal experiences and parents can always seize opportunities such as television scenes to discuss sexual topics with their children (Baku et al., 2018). There was a study that showed consistent links between parent-adolescent sexual communication and adolescents' sexual attitudes and safe-sex efficacy which in turn may influence their sexual intentions and behaviors (Rogers, 2017). The study reveals that communication regarding sexual and reproductive issues between parents and female adolescents is limited in Indonesia. (Nurachmah et al., 2018). Another findings was highlighted mothers' and daughters' motivations, risks and benefits while also contributing a new privacy rule applicable to mother-daughter sexual communication (Coffelt, 2017). If the parents have warm communication approach, then it will influence the adolescent to talk and communicate with parents. So, the parent should be creative and find the right time to talk with the adolescents. Always check on the adolescents, if something looks weird and fishy try to make a conversation with them. 
INTERNATIONAL JOURNAL OF ACADEMIC RESEARCH IN BUSINESS AND SOCIAL SCIENCES Vol. 10, No. 3, March, 2020, E-ISSN: 2222-6990 @ 2020 HRMARS

\section{Improving Sexual Health Education Programs}

The awareness about the important of sexuality education should be spread widely, for example through sexual health education program, so the adolescents can understand and use as a guidance because there are some program that effective to the adolescents like the results revealed, that most of the adolescents who participated in this programmed has increment on their sexual and reproductive health knowledge after they have been introduced to both interventions. This result suggests that both online education and conventional methods were able to upgrade adolescents' knowledge about sexual reproductive health (Farid et al., 2018).

Besides that, parents and guardians are a major influence in the lives of adolescents, and young people are more likely to respond to programs that are supported by their families than to ones that are not, so the implementation of program involved all family members will give more benefit and they can discuss together and then understand well. So, due to important roles of parents and families to their adolescents' lives, and these stakeholders need to be informed about the advantage of sexuality education and have the chance to share their thoughts and ideas (Boonstra, 2011).

Next, due to the challenging situation faced by adolescents, there is a need for improvements of the program. So, teacher is another important person for adolescents, the teacher should get adequate training regarding sexuality education For instance, the study by (Haruna et al., 2018), suggests that the two innovative teaching approaches can be used to improve the sexual health education of adolescent students. The methods can plausibly provide socially, particularly in improving sexual health behavior and adolescents' knowledge in regions plagued by years of sexual health problems, including HIV/AIDS.

Moreover, in order to improve the program regarding the sexual education further step towards designing preventative strategy may need to be considered to integrate both Islamic-based program and self-control input to increase mental health and behavioral adjustment of Muslim adolescents (Kadri et al., 2019).

\section{Reaching at Risk Adolescents}

This vulnerable group needs awareness about sexuality education, so the community-based care and programs are important for reaching orphans, adolescents living on the streets, and other adolescents detached from formal educational systems. Getting into these adolescents are significant because that vulnerable adolescents frequently experience economic hardships and other risk factors that may increase their risk of negative health outcomes (Mullinax, Mathur \& Santelli, 2017). Besides that, it will be beneficial if the mass media were used as a medium to come out with the campaigns regarding sexual education, For instance, the Straight Talk program in Uganda, implemented in 1993 and focuses on sexuality education bring on by mass media campaign which is targeting adolescents (Adamchak et al., 2007).

\section{The Importance of Sexuality Education}

Comprehensive sexuality education must equip young people with the knowledge, skills, attitudes and values they need to determine and enjoy their sexuality - physically and emotionally, individually and in relationships. It views sexuality holistically and within the context of emotional and social development. Information is not enough. Young people need to be given the opportunity to acquire essential life skills and develop positive attitudes and values. (Apter \& Cartes, 2012). 
Sexuality education is a lifelong process of acquiring information and forming attitudes, beliefs and values about identity, relationships and intimacy. It encompasses sexuality development, reproductive health, interpersonal relationships, affection, intimacy, body image and gender roles (Lukolo \& Dyk, 2015). The salient of education of sexuality are needed because it may also be associated with negative outcomes, if the sexual activity are involving at too early an age, or without due attention to the risks involved (Belinda, Richter, Richter, \& Jay, 2015) Moreover, adolescent may face many sexual and reproductive health risks derive from from early, unprotected, or unwanted sexual activity (WHO, 2012) if they are not educated about sexuality. For example, early initiation of sexual activity rise the period adolescents and they are exposed to the risk of sexually transmitted infections or unintended pregnancy (WHO, 2011).

A research in England has stated that the educational are statistically significant reductions in teenage pregnancy (Girma \& Paton, 2015). Besides that, sexuality education also as part of "promoting the well-being of adolescents, enhancing gender equality and equity as well as responsible sexual behavior, to protect them from early and unwanted pregnancy, sexually transmitted diseases including human immunodeficiency syndrome (HIV)/AIDS, and sexual abuse, incest and violence (Haberland \& Rogow, 2015). Studies in Finland and Chile has suggested an important role of sexuality education in their country because there have evidently, there were reductions in the prevalence of pregnancies, with a very special emphasis on those terminated by an induced abortion or an abortion forced by parents or other relatives (Apter \& Cartes, 2012). A study in Malaysia revealed almost half (49.3\%) of the respondents agreed that sexual education might help to overcome the social illness among school teenagers (Mohd Mutalip \& Mohamed, 2012) Moreover, other study has showed majority of adolescents i.e., $93.5 \%$ favors sex education. An $86.3 \%$ said sex education can prevent the occurrence of AIDS and $91.5 \%$ of adolescents prefer doctors should give them sex education followed by $83.0 \%$ school/teacher and least preference was parents $37.3 \%$ (Kumar et al., 2017) So, from the past research it is showed the needs of sex education should be implement accurately with being supervises by authorities.

\section{Implication of Practitioner}

Sexuality education is significant for adolescent development, where mothers can educate their child, but it will be greater if being involving by counselors, teachers and educator. If implemented correctly, sex education teaches students about anatomy and physiology, healthy relationships, hygiene, positive self-image, how to handle uncomfortable situations, and about health resources available to them. Counselors are in a best position to play a critical role in policy change regarding sex education. As a professional, counselors have the responsibility to advocate for legislation that enhances the sexual health and well-being of adolescents. Counselors should take the lead in raising awareness among parents, teachers, administrators, and staff about the implementation and success stories of adolescent's sexual health outcomes. Strategies for raising awareness might include such activities as school presentations at parent teacher's association, faculty, school board, and community meetings to draw attention to the issue and gain support. Further, counselors can seek political sponsors to make proposals, rally cosponsors for support, and give testimony to the effectiveness of sex education program. 
INTERNATIONAL JOURNAL OF ACADEMIC RESEARCH IN BUSINESS AND SOCIAL SCIENCES

Vol. 10, No. 3, March, 2020, E-ISSN: 2222-6990 @ 2020 HRMARS

\section{Conclusion}

Well-informed and prepared mothers are thought to be the best sources of sexual health education for adolescent girls; therefore, mothers should be trained for effective communication regarding sexual health issues. Besides that, discussions of sexuality education issues with adolescents need to be understand carefully. Attractive and gentle communication with adolescents are necessary in order to convey the right and acceptable knowledge. Mothers need to realize that communication is at times give and take them a chance whether to start of interesting topics, embarrassment, and fear. Developing appropriate program that will enhance the credibility of mother will be helpful and can be used in parent training course.

\section{Acknowledgement}

This research is part of a requirements to graduate in PhD study. The authors of this article would like to thank and appreciate all those who assisted with the comments to improvise the manuscript.

\section{Corresponding Author}

Melati Sumari, Ph.D

Senior Lecturer

Department of Educational Psychology \& Counselling

Faculty of Education University of Malaya

Email: melati@um.edu.my.

\section{References}

Adamchak, S. E., Kiragu, K., Watson, C., Muhwezi, M., Nelson, T., Akia-fiedler, A., ... Juma, M. (2007). The Straight Talk Campaign in Uganda : Impact of Mass Media Initiatives Horizons Program Straight Talk Foundation The Straight Talk Campaign in Uganda : Impact of Mass Media Initiatives Summary Report.

Apter, D., \& Cartes, R. M. (2012). Sexuality Education : Finnish and Chilean, 22, 332-356.

Ashcraft, A. M., \& Murray, P. J. (2017). Tal k ing t o Paren t s A b ou t Adolescent Sexuality. Pediatric Clinics of NA, 64(2), 305-320. https://doi.org/10.1016/j.pcl.2016.11.002

Askelson, N. M., Campo, S., \& Smith, S. (2012). Mother - Daughter Communication About Sex : The Influence of Authoritative Parenting Style Mother - Daughter Communication About Sex : The Influence of Authoritative Parenting Style. Health Communication, 27(5), 439-448. https://doi.org/10.1080/10410236.2011.606526

Baku, E. A., Agbemafle, I., Kotoh, A. M., \& Adanu, R. M. K. (2018). Parents ' Experiences and Sexual Topics Discussed with Adolescents in the Accra Metropolis, Ghana : A Qualitative Study. Advances in Public Health, 1-12.

Belinda, B., Richter, L., Richter, L., \& Jay, S. A. (2015). Minimum Marriage Age Laws and the Prevalence Of Child Marriage and Adolescent Birth : Evidence from Sub-Saharan Africa. 58 International Perspectives on Sexual and Reproductive Health, 41(2), 58-68. https://doi.org/10.1363/4105815

Boonstra, H. D. (2011). Advancing Sexuality Education in Developing Countries : Evidence and Implications. Guttmacher Policy Review, 14(3), 17-23.

Breuner, C. C., \& Mattson, G. (2016). Sexuality Education for Children and Adolescents. American 
INTERNATIONAL JOURNAL OF ACADEMIC RESEARCH IN BUSINESS AND SOCIAL SCIENCES

Vol. 10, No. 3, March, 2020, E-ISSN: 2222-6990 @ 2020 HRMARS

Academy of Pediatrics, 138(2), 1-10. https://doi.org/10.1542/peds.2016-1348

Coffelt, T. A. (2010). Is Sexual Communication Challenging Between Mothers and Daughters ? Journal of Family Communication, 10(2), 116-130.

https://doi.org/10.1080/15267431003595496

Coffelt, T. A. (2017). Deciding to reveal sexual information and sexuality education in motherdaughter relationships in mother-daughter relationships. Sex Education, 17(5), 1-18. https://doi.org/10.1080/14681811.2017.1326377

Dennis, A. C., \& Wood, J. T. (2012). “"We” re Not Going to Have This Conversation , But You Get It ": Black Mother - Daughter Communication About Sexual Relations. Women's Studies in Communication, 25, 204-223. https://doi.org/10.1080/07491409.2012.724525

Fortenberry, J. D. (2013). Chapter 7. Sexual Development in Adolescents. Handbook of Child and Adolescent Sexuality (First Edition). Elsevier Inc. https://doi.org/10.1016/B978-0-12-3877598.00007-6

Girma, S., \& Paton, D. (2015). Social Science \& Medicine Is education the best contraception : The case of teenage pregnancy in. Social Science \& Medicine, 131, 1-9. https://doi.org/10.1016/j.socscimed.2015.02.040

Haberland, N., \& Rogow, D. (2015). Sexuality Education : Emerging Trends in Evidence and Practice. Journal of Adolescent Health, 56(1), S15-S21.

https://doi.org/10.1016/j.jadohealth.2014.08.013

Haruna, H., Hu, X., Kai, S., Chu, W., Mellecker, R. R., Gabriel, G., \& Ndekao, P. S. (2018). Improving Sexual Health Education Programs for Adolescent Students through Game-Based Learning and Gamification. International. Journal of . Environ. Research and. Public Health, 15(2027), 1-26. https://doi.org/10.3390/ijerph15092027

Kadri, N. M., Zulkefly, N. S., \& Baharudin, R. (2019). Structural Relations amongst Religiosity, Selfcontrol, and Externalizing Problems of Juveniles in Malaysia. Malaysian Journal of Medicine and Health Sciences, 15, 68-75.

Kar, S. K., Choudhury, A., \& Sigh, A. P. (2015). Understanding normal development of adolescent sexuality : A bumpy ride. Journal of Human Reproductive Sciences, 8(2), 70-74. https://doi.org/10.4103/0974-1208.158594

Keizer, R. (2019). Perceived Quality of the Mother - Adolescent and Father - Adolescent Attachment Relationship and Adolescents' Self-Esteem. Journal of Youth and Adolescence, 1203-1217. https://doi.org/10.1007/s10964-019-01007-0

Kumar, R., Goyal, A., Singh, P., Bhardwaj, A., Mittal, A., \& Yadav, S. S. (2017). Knowledge Attitude and Perception of Sex Education among School Going Adolescents in Ambala District, Haryana , India : A Cross-Sectional Study. Journal of Clinical and Diagnostic Research., 11(3), 1-4. https://doi.org/10.7860/JCDR/2017/19290.9338

Lukolo, L. N., \& Dyk, A. Van. (2015). Parents' Participation in the Sexuality Education of Their Children in Rural Namibia : A Situational Analysis. Global Journal of Health Science, 7(1), 35-45. https://doi.org/10.5539/gjhs.v7n1p35

Mark, K. M., \& Pike, A. (2016). Links between marital quality, the mother - child relationship and child behavior : A multi-level modeling approach. International Journal of Behavioral Development, 41(2), 1-10. https://doi.org/10.1177/0165025416635281

Mohd Mutalip, S. S., \& Mohamed, R. (2012). Sexual Education In Malaysia : Accepted Or Rejected ? 
INTERNATIONAL JOURNAL OF ACADEMIC RESEARCH IN BUSINESS AND SOCIAL SCIENCES

Vol. 10, No. 3, March, 2020, E-ISSN: 2222-6990 @ 2020 HRMARS

Iranian Journal Public Health, 41(7), 34-39.

Moshman, D. (2014). Sexuality Development in Adolescence and Commentary on Arbeit. Human Development, 57, 287-291. https://doi.org/10.1159/000367857

Muhammad, N. A., Shamsuddin, K., Sulaiman, Z., Mohd Amin, R., \& Omar, K. (2016). Role of Religion in Preventing Youth Sexual Activity in Malaysia : A Mixed Methods Study. Journal of Religion and Health, 56(6), 1916-1929. https://doi.org/10.1007/s10943-016-0185-z

Muhwezi, W. W., Katahoire, A. R., Banura, C., Mugooda, H., Kwesiga, D., Bastien, S., \& Klepp, K. (2015). Perceptions and experiences of adolescents, parents and school administrators regarding adolescent-parent communication on sexual and reproductive health issues in urban and rural Uganda. Reproductive Health, 1-16. https://doi.org/10.1186/s12978-015-0099-3

Mullinax, M., Mathur, S., \& Santelli, J. (2017). Adolescent Sexual Health and Sexuality Education. International Handbook on Adolescent Health and Development, 143-167. https://doi.org/10.1007/978-3-319-40743-2

Nik Farid, N. D., Mohd Arshad, M. F., Yakub, N. A., Ahmad Zaki, R., Muhamad, H., Aziz, N. A., \& Dahlui, M. (2018). Improving Malaysian adolescent sexual and reproductive health : An Internet-based health promotion programme as a potential intervention. Health Education Journal, 77(7), 837-848. https://doi.org/10.1177/0017896918778071

Nurachmah, E., Afiyanti, Y., Yona, S., Ismailb, R., Padang, J. T., Suardana, I. K., ... Dharma, K. K. (2018). Mother-daugther communication about sexual and reproductive health issues in Singkawang, West Kalimantan, Indonesia. Enferia Clinica, 28(1), 172-175. https://doi.org/10.1016/S1130-8621(18)30061-5

Opara, I., Eke, G., \& Akani, A. (2010). Mothers Perception of Sexuality Education for Children Mothers Perception of Sexuality Education for Children. Nigerian Journal of Medicine, 19(2), 168-172. https://doi.org/10.4314/njm.v19i2.56513

Pfeffer, B., \& Ellsworth, T. R. (2017). Interviewing Adolescents About Sexual Matters. Pediatric Clinics of NA, 64(2), 291-304. https://doi.org/10.1016/j.pcl.2016.11.001

Pringle, J., Mills, K. L., Mcateer, J., Jepson, R., Hogg, E., \& Anand, N. (2017). The physiology of adolescent sexual behaviour : A systematic review. Cogent Social Sciences, 56, 1-14. https://doi.org/10.1080/23311886.2017.1368858

Rogers, A. A. (2017). Parent - Adolescent Sexual Communication and Adolescents ' Sexual Behaviors : A Conceptual Model and Systematic Review. Adolescent Research Review, 2(4), 293-313. https://doi.org/10.1007/s40894-016-0049-5

Shams, M., Parhizkar, S., Mousavizadeh, A., \& Majdpour, M. (2017). Mothers ' views about sexual health education for their adolescent daughters : a qualitative study, 1-6. https://doi.org/10.1186/s12978-017-0291-8

Walper, S. (2015). Adolescent relationships with mother and father and their links to the quality of romantic relationships : A classification approach. European Journal of Adolescents, 1-19. https://doi.org/10.1080/17405629.2015.1065727

WHO. (2018). WHO recommendations on adolescent sexual and reproductive health and rights.

World Health Organization (WHO). (2011). The sexual and reproductive health of younger adolescents.

World Health Organization (WHO). (2012). Expanding contraceptive choice. https://doi.org/10.1363/3913313.Ross. 